\title{
The influence of riparian vegetation, woody debris, stream morphology and human activity on the use of rivers by southern river otters in Lontra provocax in Chile
}

\author{
Gonzalo Medina-Vogel, Vera S. Kaufman, René Monsalve and Vicente Gomez
}

\begin{abstract}
The distribution of the Endangered southern river otter Lontra provocax population in southern Chile has contracted, causing concern among otter specialists and conservationists. The main factor contributing to this decline is the loss of suitable habitat. Because the Chilean Irrigation Law promotes land drainage, the removal of riparian vegetation and canalization of lowland rivers in several provinces, this situation could deteriorate further. Using an Index of Revisitation Rate (IRR), we assessed the influence of woody debris, riparian vegetation, river bank morphology and river canalization on the use of rivers and streams by the southern river otter. Surveys were conducted on foot, on a monthly basis, between April 1999 and March 2001 in the south of Chile. The surveys covered 13 sections of rivers and streams, $3 \mathrm{~km}$ long and $<50 \mathrm{~m}$ wide. River and stream banks with high density of riparian vegetation, woody debris and exposed
\end{abstract}

roots had the highest IRR; most of the highly marked sprainting sites were found in this habitat. Canalized rivers and streams lacking these characteristics had the lowest IRR and hardly any highly marked sprainting sites. The data indicates that otters can tolerate some degree of riparian vegetation removal, provided there is minimum use of floodplains by humans. Temperate evergreen ombrophilus swamp forests and shallow watercourses with woody debris or gravel, riparian vegetation and a plentiful supply of macrocrustaceans appear to be the preferred habitat and conditions for the otter and may be key to its survival in freshwater habitats.

Keywords Chile, Lontra provocax, macrocrustaceans, otter field signs, riparian vegetation, river canalization, woody debris.

\section{Introduction}

The southern river otter Lontra provocax (nutria de río or huillín) of southern Chile and Argentina is categorized as Endangered on the IUCN Red List of Threatened Species (IUCN, 2002). Historically the distribution of the species was more extensive, in rivers, streams and fiords from the Cauquenes and Cachapoal rivers $\left(34^{\circ} \mathrm{S}\right)$ to the Magellan region $\left(53^{\circ} \mathrm{S}\right)$ in Chile, and from the Andes to the Pacific (Osgood, 1943; Medina, 1996). At present, populations in freshwater habitats have been confirmed in only a few isolated areas, from 39 to $44^{\circ} \mathrm{S}$ (Medina, 1996). The major factor leading to the decline in the species distribution is habitat degradation (Melquist, 1984; Medina, 1996). Lack of riparian vegetation, woody debris, roots and gravel deposited after canalization and dredging may make otters more vulnerable to human

Gonzalo Medina-Vogel (Corresponding author) Vera S. Kaufman René Monsalve and Vicente Gomez Instituto de Ecología y Evolución, Universidad Austral de Chile, Casilla 567, Valdivia, Chile. E-mail: gmedina@uach.c

Received 28 August 2002. Revision requested 13 March 2003. Accepted 19 June 2003 disturbance and reduce the carrying capacity of their habitat (Melquist \& Hornocker, 1983; Boon, 1992; Crook \& Robertson, 1999). Water depth, surface area and flow affect prey availability and vulnerability, and all of these factors can affect the distribution and spatial patterns of otters (Kruuk, 1995).

The Irrigation Law (Lay para el Formento del Riego y Drenage) passed in Chile in 1986 promotes investment in land drainage and consequently encourages the removal of riparian vegetation and the canalization of lowland rivers, in particular those rivers that flow through swamp forest. Moreover, the government will finance up to $75 \%$ of the total cost of such works (Guajardo, 2001). Because of this approach to river management, compounded by farmers' and authorities' lack of knowledge of the habitat of the southern river otter and the threats to its existence, there is an urgent need for reliable information on the effect of the removal of riparian vegetation and river canalization on the southern river otter and its freshwater habitat. The purpose of this study was to assess the differences between canalized and non-canalized rivers and streams, their riparian vegetation, river bank morphology and woody debris, and the otter's utilization of these habitats, by analysing an Index of Revisitation Rate and the otter's marking behaviour. 


\section{Methods}

\section{Study area}

The study was conducted in southern Chile $\left(39^{\circ} \mathrm{S}, 72^{\circ} \mathrm{W}\right.$; Fig. 1) along rivers and streams with unconfined channels. These watercourses are dune-ripple, except at their source in the mountains, where they are normally pool-riffle (Montgomery \& Buffington, 1998) (Fig. 1). The rivers and streams studied form a network of first- and secondorder watercourses, with their source not further than $150 \mathrm{~km}$ from the sea (Fig. 1). The maximum flow of these watercourses can be up to $c .14$ times the minimum flow, and during times of high water levels adjacent plains and riparian zones are flooded. The study area is located in a region with a humid-temperate climate and an average annual rainfall of $2,110 \mathrm{~mm}$, with minimum levels of rainfall recorded in summer (January-March) and maximum levels in winter (June-August) (Campos, 1985). The rivers and streams studied are or were partially covered by a temperate, evergreen, ombrophilous swamp forest, a native vegetation community composed mainly of Myrceugenia exsucca, Temu divaricatum and Drimys winteri (Ramirez et al., 1983).

\section{Habitat use by southern river otter}

Between April 1999 and March 2001 both banks of 13 sections ( $3 \mathrm{~km}$ long and $<50 \mathrm{~m}$ wide) of river or stream were surveyed on foot during one day, and all sections were surveyed within a period of 2 months. Every section was surveyed 9-11 times (depending on the occurrence of flooding) during the research period. The habitat of each section was sampled in $10 \mathrm{~m}$ long segments every $100 \mathrm{~m}$ of watercourse, including the water surface, and up to $10 \mathrm{~m}$ inland along both river banks.
Thereafter the habitat was classified depending on the amount of riparian vegetation cover as a percentage of the total surface area (low, $<33 \%$; medium, 34-66\%; high, $>67 \%$ ), large woody debris, exposed roots, the existence of channel walls (above the river banks) and stream width and depth. Human activity and land use were also described up to $500 \mathrm{~m}$ from each bank.

In each study section a 'positive site' was defined as a site where dens/shelters, latrines, or sandy shores with new (not older than 2 months) otter field signs (spraints, anal smears, footprints or urine) were found. Only positive sites separated by more than $5 \mathrm{~m}$ were considered to be different (Melquist \& Hornocker, 1983; Newman \& Griffin, 1994; Medina, 1996). Positive sites were tagged in the field, their location was plotted on 1:50,000 maps, and they were classified in four categories used in the calculation of an Index of Revisitation Rate (IRR): A, those visited by otters only once in a 6-month period (non-permanent); $\mathrm{B}$, those visited by otters more than three times in a 6-month period (permanent); C, those heavily marked or with a total accumulation of more than 10 spraints in a 1 -year period; $\mathrm{D}$, those with only one spraint in a 1-year period. Category $\mathrm{C}$ could include category A and B, and category D could include category $\mathrm{A}$. In order to assess the otter's marking behaviour the tree and bush cover as a percentage of the total surface area (low, $<33 \%$; medium, 34-66\%; high, $>67 \%$ ) was recorded within a $5 \mathrm{~m}$ radius of each positive site, and within a $5 \mathrm{~m}$ radius of a second randomly selected site located 10-100 m to the left or right of each positive site, parallel to the watercourse.

The Index of Revisitation Rate (IRR) was calculated by dividing the number of positive sites by the proportion of the actual distance walked. Each positive site was weighted equally, irrespective of the numbers of spraints, smears or footprints (Newman \& Griffin, 1994;
Fig. 1 The location of the 13 river sections surveyed. The solid circle on the inset map of South America indicates the position of the main figure in Chile.

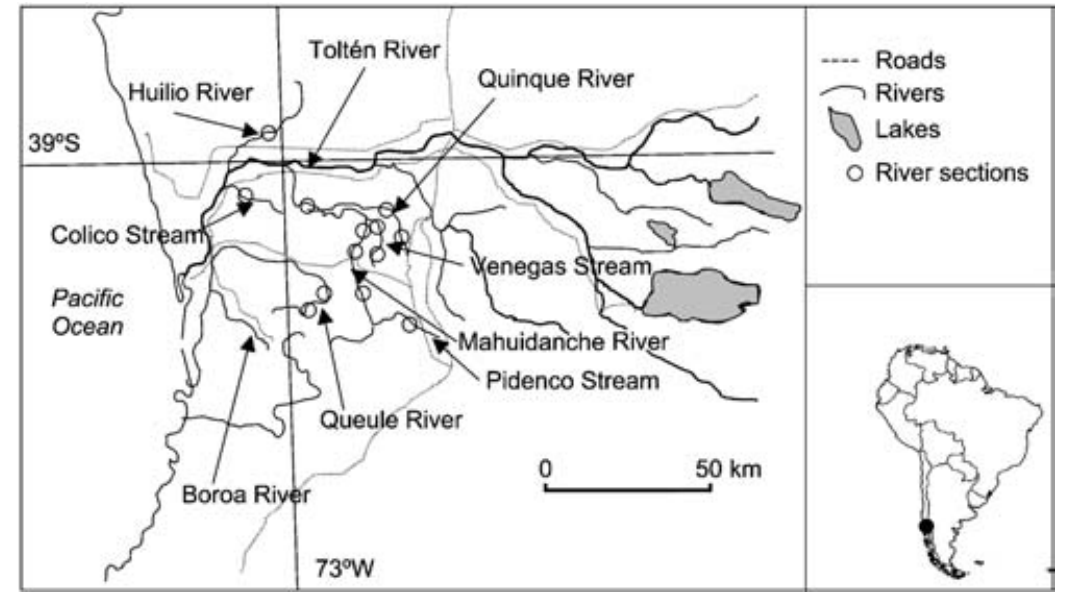


Ruiz-Olmo \& Gonsálbez, 1997). The proportion of the actual distance walked along each section was used to avoid bias due to variation in distance walked during flooding; the maximum distance that could be surveyed on each section was $6 \mathrm{~km}$ (i.e. $3 \mathrm{~km}$ for each bank). Thus, for example, if one section recorded three positive sites and the actual distance walked was $5 \mathrm{~km}$ rather than the full length of $6 \mathrm{~km}$, its IRR was $3 / 0.83=3.6$, where 0.83 is $5 / 6$. Spraints were collected on a monthly basis in order to analyse diet (Medina, 1998).

\section{Statistical Analyses}

A General Linear Model (GLM) for unbalanced designs and repeated measurements was used to explore the influence of the independent variables (the sections and the habitat characteristics of each section) on the IRR (Thomas \& Taylor, 1990; Kirby, 1993; Macdonald et al., 2002a). For all post-hoc comparisons the multiple comparison Tukey HSD test was used (Thomas \& Taylor, 1990; Kirby, 1993; Wilkinson et al., 1996; Macdonald et al., 2002a). The effect of canalization was assessed by comparing canalized sections with those not canalized from the same rivers. Habitat differences between categories of positive sites, as well as between positive sites and randomly selected sites, were assessed using the $\chi^{2}$ test (Newman \& Griffin, 1994; Ruiz-Olmo \& Gonsálbez, 1997). All data were transformed to $\log (x+1)$ prior to analysis to produce a normal distribution (Krebs, 1989). Significance was set at $\mathrm{P}<0.05$ throughout, and all statistical tests were carried our using SYSTAT v. 6.0.

\section{Results}

This study recorded differences in the Index of Revisitation Rate (IRR; Fig. 2) between river and stream sections (Table 1), and there were significant differences among the 13 sections $(F=36.8$; d.f. $=12,125 ; \mathrm{P}<0.01)$. Intersectional comparisons (with the Tukey HSD test) showed that non-canalized sections with medium or high riparian vegetation cover had a significantly higher IRR than canalized sections with low or medium riparian vegetation cover and no or low woody debris ( 1 vs 5 and 13; 7 vs 13; 10 vs 5 and 13; 11 vs 5 and 13; 2 vs 5, 9 and 13) (Table 2).

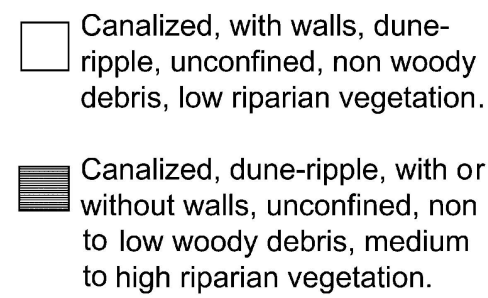
to high riparian vegetation.
Non-canalized, with walls, dune-ripple, unconfined, low woody debris, medium riparian vegetation.

Non-canalized, without walls, dune-ripple, unconfined, high woody debris, high riparian vegetation.

Non-canalized, with walls, pool-riffle, unconfined or confined, low woody debris, medium to high riparian vegetation.

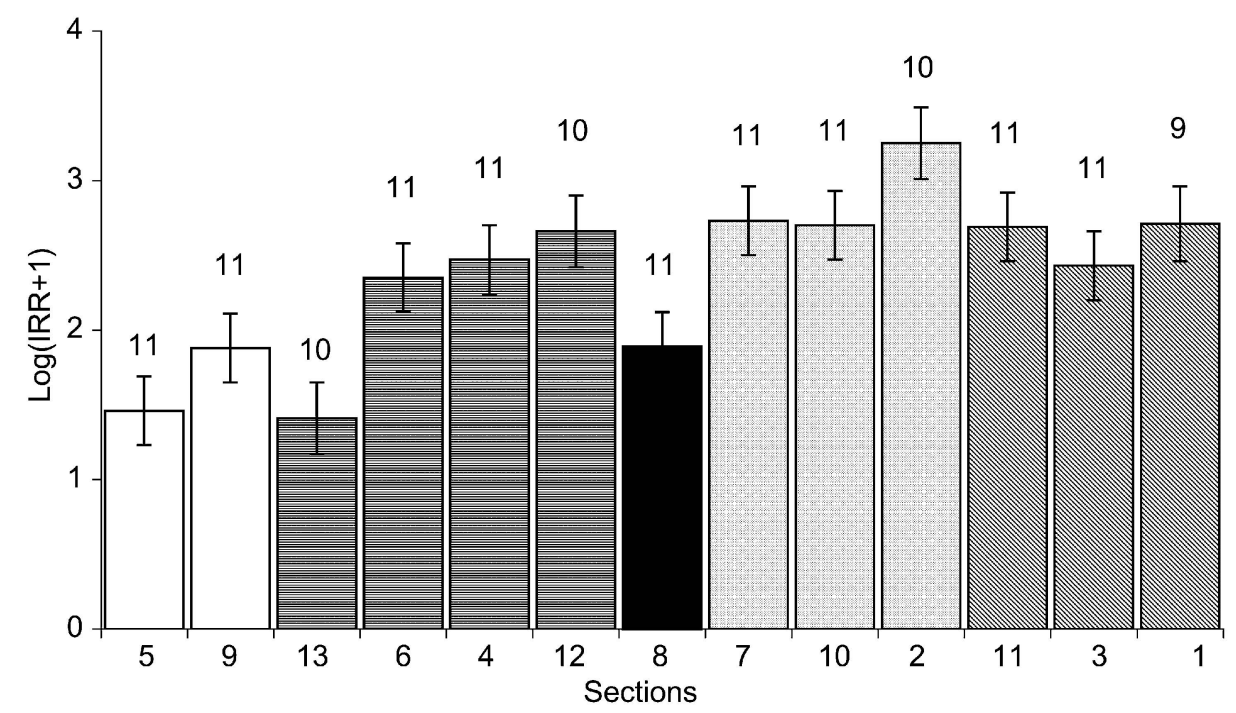

Fig. 2 Mean Index of Revisitation Rate $(\log +1)$ for each surveyed river section, with standard error bars. The shading indicates the habitat characteristics of each section, and the numbers indicate the number of surveys of each section. 
Table 1 Habitat characteristics and classification for the 13 river and stream sections studied (see Fig. 1 for locations).

\begin{tabular}{|c|c|c|c|c|c|c|c|c|}
\hline \multirow[b]{2}{*}{$\begin{array}{l}\text { Section } \\
\text { no. }\end{array}$} & \multirow[b]{2}{*}{ River or stream name } & \multicolumn{7}{|c|}{ Habitat characteristics } \\
\hline & & $\begin{array}{l}\text { Artificially } \\
\text { canalized }\end{array}$ & $\begin{array}{l}\text { Woody debris, } \\
\text { above ground } \\
\text { roots and } \\
\text { shoreline walls }\end{array}$ & $\begin{array}{l}\text { Riparian } \\
\text { vegetation } \\
\text { density }\end{array}$ & $\begin{array}{l}\text { Channel } \\
\text { reaches } \\
\text { and } \\
\text { bounds }\end{array}$ & $\begin{array}{l}\text { Stream } \\
\text { width } \\
(\mathrm{m})\end{array}$ & $\begin{array}{l}\text { Stream } \\
\text { depth } \\
(\mathrm{m})\end{array}$ & $\begin{array}{l}\text { Human presence } \\
\text { and activity }\end{array}$ \\
\hline 1 & Pidenco, Pidenco Stream & No & $\begin{array}{l}\text { Low, } \\
\text { with walls }\end{array}$ & Medium & $\begin{array}{l}\text { Pool-riffle, } \\
\text { unconfined }\end{array}$ & $<7$ & $<1$ & Sporadic, restricted \\
\hline 2 & $\begin{array}{l}\text { Ocho puentes Mahuidanche } \\
\text { River }\end{array}$ & No & $\begin{array}{l}\text { High, } \\
\text { without walls }\end{array}$ & High & $\begin{array}{l}\text { Dune-ripple, } \\
\text { unconfined }\end{array}$ & $7-14$ & $<1$ & Very rare, very low \\
\hline 3 & Queule, Queule River & No & $\begin{array}{l}\text { Low, } \\
\text { with walls }\end{array}$ & Medium & $\begin{array}{l}\text { Pool-riffle, } \\
\text { unconfined }\end{array}$ & $>14$ & $1-2$ & Sporadic, restricted \\
\hline 4 & $\begin{array}{l}12 \text { Puentes, Mahuidanche } \\
\text { River }\end{array}$ & Yes & $\begin{array}{l}\text { No, } \\
\text { with walls }\end{array}$ & Medium & $\begin{array}{l}\text { Dune-ripple, } \\
\text { unconfined }\end{array}$ & $7-14$ & $1-2$ & Vary rare, very low \\
\hline 5 & $\begin{array}{l}\text { Nueva Etruria Mahuidanche } \\
\text { River }\end{array}$ & Yes & $\begin{array}{l}\text { No, } \\
\text { with walls }\end{array}$ & Low & $\begin{array}{l}\text { Dune-ripple, } \\
\text { unconfined }\end{array}$ & $7-14$ & $1-2$ & Permanent, intense \\
\hline 6 & $\begin{array}{l}\text { Quinque Alto, Quinque } \\
\text { River }\end{array}$ & Yes & $\begin{array}{l}\text { No, } \\
\text { without walls }\end{array}$ & Medium & $\begin{array}{l}\text { Dune-ripple, } \\
\text { unconfined }\end{array}$ & $7-14$ & $<1$ & Sporadic, restricted \\
\hline 7 & $\begin{array}{l}\text { Quinque Medio, Quinque } \\
\text { River }\end{array}$ & No & $\begin{array}{l}\text { High, } \\
\text { without walls }\end{array}$ & High & $\begin{array}{l}\text { Dune-ripple, } \\
\text { unconfined }\end{array}$ & $>14$ & $<1$ & Sporadic, restricted \\
\hline 8 & $\begin{array}{l}\text { Mahuidanche, Mahuidanche } \\
\text { River }\end{array}$ & No & $\begin{array}{l}\text { Low, } \\
\text { with walls }\end{array}$ & Medium & $\begin{array}{l}\text { Dune-ripple, } \\
\text { unconfined }\end{array}$ & $>14$ & $>2$ & Permanent, intense \\
\hline 9 & Venegas, Venegas Stream & Yes & $\begin{array}{l}\text { No, } \\
\text { with walls }\end{array}$ & Low & $\begin{array}{l}\text { Dune-ripple, } \\
\text { unconfined }\end{array}$ & $<7$ & $1-2$ & Permanent, intense \\
\hline 10 & Huilio, Huilio River & No & $\begin{array}{l}\text { High, } \\
\text { without walls }\end{array}$ & High & $\begin{array}{l}\text { Dune-ripple, } \\
\text { unconfined }\end{array}$ & $>14$ & $<1$ & Sporadic, restricted \\
\hline 11 & Queule Alto, Queule River & No & $\begin{array}{l}\text { Low, } \\
\text { with walls }\end{array}$ & High & $\begin{array}{l}\text { Pool-riffle, } \\
\text { confined }\end{array}$ & $>14$ & $1-2$ & Rare, low \\
\hline 12 & Venegas Alto, Venegas Stream & Yes & $\begin{array}{l}\text { No, } \\
\text { without walls }\end{array}$ & High & $\begin{array}{l}\text { Dune-ripple, } \\
\text { unconfined }\end{array}$ & $<7$ & $1-2$ & Rare, low \\
\hline 13 & Colico, Colico Stream & Yes & $\begin{array}{l}\text { Low, } \\
\text { without walls }\end{array}$ & Medium & $\begin{array}{l}\text { Dune-ripple, } \\
\text { unconfined }\end{array}$ & $<7$ & $<1$ & Sporadic, restricted \\
\hline
\end{tabular}

Table 2 Probabilities of the post-hoc Tukey HSD tests for inter-sectional comparisons of the Index of Revisitation Rate (see text for details). Significant differences $(\mathrm{P}<0.05)$ are indicated in bold italics.

\begin{tabular}{|c|c|c|c|c|c|c|c|c|c|c|c|c|c|}
\hline \multirow[b]{2}{*}{ Section no. } & \multicolumn{13}{|c|}{ Section no. } \\
\hline & 1 & 2 & 3 & 4 & 5 & 6 & 7 & 8 & 9 & 10 & 11 & 12 & 13 \\
\hline 1 & & 0.94 & 1.00 & 1.00 & 0.02 & 1.00 & 1.00 & 0.45 & 0.41 & 1.00 & 1.00 & 1.00 & 0.01 \\
\hline 2 & 0.94 & & 0.39 & 0.48 & $<0.01$ & 0.25 & 0.94 & $<0.01$ & $<0.01$ & 0.91 & 0.90 & 0.88 & $<0.01$ \\
\hline 3 & 1.00 & 0.39 & & 1.00 & 0.12 & 1.00 & 1.00 & 0.91 & 0.89 & 1.00 & 1.00 & 1.00 & 0.10 \\
\hline 4 & 1.00 & 0.48 & 1.00 & & 0.12 & 1.00 & 1.00 & 0.86 & 0.84 & 1.00 & 1.00 & 1.00 & 0.07 \\
\hline 5 & 0.02 & $<0.01$ & 0.12 & 0.12 & & 0.21 & 0.01 & 0.98 & 0.99 & 0.01 & 0.01 & 0.02 & 1.00 \\
\hline 6 & 1.00 & 0.25 & 1.00 & 1.00 & 0.21 & & 1.00 & 0.97 & 0.96 & 1.00 & 1.00 & 1.00 & 0.18 \\
\hline 7 & 1.00 & 0.94 & 1.00 & 1.00 & 0.01 & 1.00 & & 0.32 & 0.29 & 1.00 & 1.00 & 1.00 & $<0.01$ \\
\hline 8 & 0.45 & $<0.01$ & 0.91 & 0.86 & 0.98 & 0.97 & 0.32 & & 1.00 & 0.38 & 0.40 & 0.50 & 0.96 \\
\hline 9 & 0.41 & $<0.01$ & 0.89 & 0.84 & 0.99 & 0.96 & 0.29 & 1.00 & & 0.35 & 0.37 & 0.46 & 0.97 \\
\hline 10 & 1.00 & 0.91 & 1.00 & 1.00 & 0.01 & 1.00 & 1.00 & 0.38 & 0.35 & & 1.00 & 1.00 & 0.01 \\
\hline 11 & 1.00 & 0.90 & 1.00 & 1.00 & 0.01 & 1.00 & 1.00 & 0.40 & 0.37 & 1.00 & & 1.00 & 0.01 \\
\hline 12 & 1.00 & 0.88 & 1.00 & 1.00 & 0.02 & 1.00 & 1.00 & 0.50 & 0.46 & 1.00 & 1.00 & & 0.01 \\
\hline 13 & 0.01 & $<0.01$ & 0.10 & 0.07 & 1.00 & 0.18 & $<0.01$ & 0.96 & 0.97 & 0.01 & 0.01 & 0.01 & \\
\hline
\end{tabular}


However, there was no significant difference in the IRR between section 12, part of a canalized stream where riparian vegetation had naturally regenerated and there was high vegetation cover, and the IRRs for non-canalized sections with high riparian vegetation cover $(2,7,10$ and 11). Section 12 had a significantly higher IRR than some canalized sections with low or medium riparian vegetation cover (5 and 13).

Non-canalized sections having walls or high river banks $(1,3,8$ and 11$)$ had significantly lower IRRs ( $F=3.0$; d.f. $=1,72 ; \mathrm{P}=0.04)$ than non-canalized sections without walls or with gently sloping banks $(2,7$ and 10$)$. Furthermore, the IRRs for canalized sections with low or medium riparian vegetation $(4,5,6$ and 9) were significantly lower $(F=4.0$; d.f. $=1,84 ; \mathrm{P}=0.01)$ than for those sections from the same rivers that were still covered with swamp forest or had high concentrations of riparian vegetation, woody debris and above ground roots (2 and 7).

Differences in IRRs grouped according to four levels of human activity (Table 1$)$ were significant $(F=6.5$; d.f. $=3$, 134; $\mathrm{P}=0.04$ ). Inter-sectional comparisons (with the Tukey HSD test) showed that sections with permanent human settlements and intense agricultural activities (5, 8 and 9) had significantly lower IRRs $(P=0.03)$ than those of sections with sporadic human presence and restricted human activity $(1,3,6,7,10$ and 13). No significant differences in IRRs were found between sections with none or low woody debris and high riparian vegetation but rare and low human presence and activity (11 and 12), and sections with medium to high riparian vegetation cover and woody debris but very rare and very low human presence and activity (2 and 4 ).

Spraints were the most recorded field signs $(3,856 ; 96 \%)$, followed by footprints $(127 ; 3 \%)$ and smears $(40 ; 1 \%)$, with significant differences between seasons $(F=33.2$; d.f. $=10$, $127 ; \mathrm{P}=0.02$ ). Inter-sectional comparisons (with the Tukey HSD test) demonstrated that field signs significantly increased $(\mathrm{P}<0.01)$ during autumn (March-May) and decreased during winter (June-August). There were significant differences in the number of signs found among sections of different water depth $(F=17.4$; d.f. $=2$, 135; $\mathrm{P}<0.01$ ), and inter-sectional comparisons (with the Tukey HSD test) showed that sections $<1 \mathrm{~m}$ deep had significantly more field signs than sections $>1 \mathrm{~m}$ deep $(\mathrm{P}<0.05)$.

Category A sites (i.e. those visited by otters only once in a 6-month period) were the most prevalent sites (309; $54 \%)$ followed by categories D $(115 ; 20 \%)$, B (91; 16\%) and $C(57 ; 10 \%)$. Almost all positive sites were $<2 \mathrm{~m}$ from a watercourse.

Within each section there was no significant difference in the concentration of trees and bushes surrounding positive sites and those surrounding randomly selected sites. Considering the distribution of positive sites separately, category C sites (i.e. those most heavily marked by otters) showed a stronger association with trees $\left(\chi^{2}=28.7 ;\right.$ d.f. $\left.=5 ; \mathrm{P}<0.05\right)$ and bushes $\left(\chi^{2}=16.0\right.$; d.f. $=5 ; \mathrm{P}<0.05)$ than category $\mathrm{D}$ sites (i.e. those with only one spraint in a 1-year period) (Table 3, Fig. 3). There were differences in the amount of category $C$ sites between sections with different habitats $(F=4.6$; d.f. $=4-8 ; \mathrm{P}=0.03)$; most $\mathrm{C}$ sites $(47 \% ; 27)$ were found in sections with swamp forest $(2,7$ and 10) and almost none $(2 \% ; 1)$ were found in the canalized sections without riparian vegetation (5 and 9). Non-canalized sections had the highest concentration $(77 \% ; 44)$ of category $C$ sites $(F=2.1$; d.f. $=1,11 ; \mathrm{P}=0.01)$. No significant differences were found between sections and habitat for category A, B and D sites.

A total of 1,144 southern river otter spraints were collected and analysed. A small species of crayfish Samastacus spinifroms was found in $85 \%$ of spraints collected, various species of fish in 9\%, eels Geotria australis in $4 \%$, a small crab Aegla sp. in 3\%, and unidentified amphibians and birds in $2 \%$.

Table 3 Number of positive sites (i.e. sites visited by southern river otters, see text for details), of four types, within each of three categories of tree and bush cover (see text for details).

\begin{tabular}{|c|c|c|c|c|c|c|c|c|c|c|c|c|c|}
\hline \multirow[b]{4}{*}{ Positive site type } & \multicolumn{12}{|c|}{ Concentration of trees and bush within a $5 \mathrm{~m}$ radius } & \multirow[b]{4}{*}{ Total } \\
\hline & \multicolumn{4}{|c|}{$0-33 \%$} & \multicolumn{4}{|c|}{$34-66 \%$} & \multicolumn{4}{|c|}{$67-100 \%$} & \\
\hline & \multicolumn{2}{|c|}{ Trees } & \multicolumn{2}{|c|}{ Bush } & \multicolumn{2}{|c|}{ Trees } & \multicolumn{2}{|c|}{ Bush } & \multicolumn{2}{|c|}{ Trees } & \multicolumn{2}{|c|}{ Bush } & \\
\hline & $\mathrm{n}$ & $\%$ & $\mathrm{n}$ & $\%$ & $\mathrm{n}$ & $\%$ & $\mathrm{n}$ & $\%$ & $\mathrm{n}$ & $\%$ & $\mathrm{n}$ & $\%$ & \\
\hline (A) Non-permanent & 214 & 69 & 261 & 84 & 57 & 18 & 38 & 12 & 38 & 12 & 10 & 3 & 309 \\
\hline (B) Permanent & 58 & 63 & 69 & 75 & 15 & 16 & 18 & 19 & 18 & 19 & 4 & 4 & 91 \\
\hline (C) Highly marked & 27 & 47 & 40 & 70 & 8 & 14 & 15 & 26 & 22 & 38 & 2 & 3 & 57 \\
\hline (D) One sign & 85 & 73 & 107 & 93 & 23 & 20 & 7 & 6 & 7 & 6 & 1 & 0 & 115 \\
\hline Total & 384 & 252 & 477 & 322 & 103 & 68 & 78 & 63 & 85 & 75 & 17 & 10 & 572 \\
\hline
\end{tabular}


Fig. 3 Percentage of positive sites of categories $\mathrm{C}$ and $\mathrm{D}$ (see text for details) classified according to the percentage of riparian vegetation within a $5 \mathrm{~m}$ radius of each site.

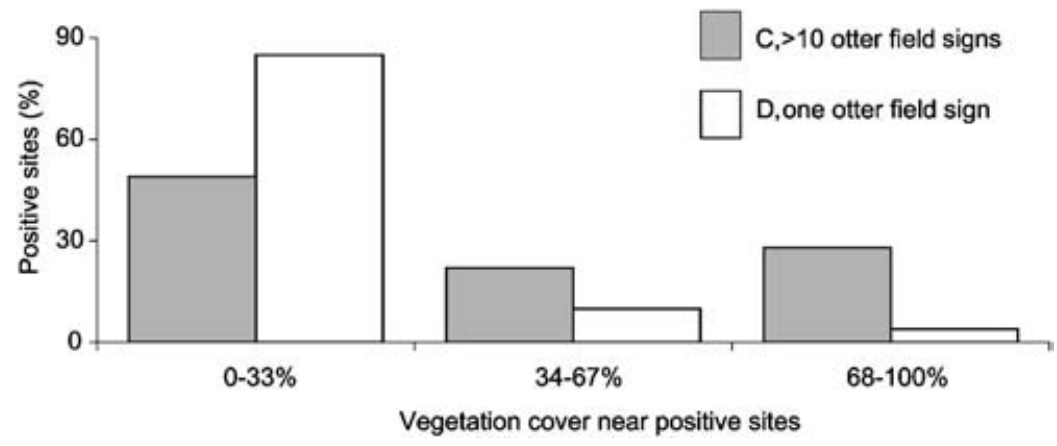

vegetation had regenerated naturally, than for canalized sections without riparian vegetation. Similar observations have been reported for L. lutra in Northumberland, UK, where field signs increased significantly after the restoration of the riparian vegetation (Andrews, 1989; Fox, 1999). Conversely, the findings of this study concerning marking behaviour indicate that otters prefer to mark in sites that have a low concentration of riparian vegetation combined with mature trees and exposed roots; this preference was also displayed by L. lutra in Europe (Macdonald et al., 1978; Andrews, 1989; Kruuk, 1995; Ruiz-Olmo \& Gonsálbez, 1997).

The fact that most sites marked by otters in this study had low concentrations of bushes and mature trees, whereas most sections with high IRRs had high concentration of riparian vegetation and woody debris can be explained by the strong variations in water levels in the study area. These variations particularly affect channels that have high, steep banks and a low concentration of riparian vegetation (Montgomery \& Buffington, 1998). Every winter, variations in water levels result in destruction of riparian vegetation, and our observations suggest that studies which record habitat features near latrines, dens or shelters close to watercourses may only consider aspects of otter marking behaviour and the channel's physical response to seasonal water variations, and not habitat selection or use. Alternatively, studies that consider the habitat of river or valley sections as the units for comparison may better describe otter requirements with regard to habitat and its use (Dubuc et al. 1990; Madsen \& Prang 2001). Further studies using the same survey methods applied in this study should consider that flooding and water levels can affect the availability of shelters, the relationship between the otter and its prey and the surveyor's ability to find field signs. During this study the water depth and conditions experienced in winter negatively affected the number of field signs found.

Human presence and disturbance brought about by agricultural practices is known to affect otters and scent-marking behaviour of mustelids (Dubuc et al., 1990; 
Newman \& Griffin, 1994; Hutchings \& White, 2000; Perrin \& Carugati, 2000). In our research the effect of human activity and presence varied between different habitat conditions. The results indicate that human activity affects IRR negatively in sections with permanent human presence and intensive agricultural activities but that this influence is modified by other habitat variables. Therefore, it seems that southern river otters can use rivers and streams with low, and sometimes permanent human activity and presence, providing there is sufficient concentration of riparian vegetation, woody debris, roots or any other habitat characteristics that provide a good supply of refuges, shelters and prey. Similar observations have been made of L. lutra in Europe (Madsen \& Prang, 2001).

Studies have shown that structurally complex aquatic habitats, such as macrophyte beds and reefs, support more diverse and abundant biotic communities than structurally simple habitats (Crook \& Robertson, 1999). The dominance of soft benthic substrata means that woody debris is the principal hard substrata for biofilm development and macroinvertebrate colonization in many lowland river channels (Crook \& Robertson, 1999). Woody debris is an important substratum for non-burrowing invertebrates in lowland rivers (Benke et al., 1984; Smock et al., 1985). Previous studies have shown that in freshwater habitats in Argentina and Chile the southern river otter eats almost only crustaceans (Chehébar et al., 1986; Medina 1998), and in our study otters appear to feed predominantly on the crustaceans S. spinifroms and Aegla sp. If sprainting serves to communicate to other otters the use of key resources (Kruuk, 1992), and as spraints were the most common field signs found in this study, then a high IRR would be expected on those sections experiencing the greatest use by otters (Kruuk, 1992; Hutchings \& White, 2000). In this study highly marked sites (type C) were also associated with the sections with swamp forest or riparian vegetation and woody debris. Therefore, the relation of highest IRR and highly marked sites to sections with high percentage of riparian vegetation, exposed roots and woody debris, shallow river and stream channels with floodplains (all habitat characteristics found in those sections with swamp forest), and river beds with abundant small to medium stones or gravel could be more closely related to the abundance of the otter's preferred prey (crustaceans) and suitable locations for shelters than to the measured habitat characteristics (Benke et al., 1984; Smock et al., 1985; Kruuk et al., 1993; Crook \& Robertson, 1999; White et al., in press)

The decline of lowland river fisheries throughout the world may be attributed to large-scale loss of the complex habitat structure of lowland rivers. This is predominantly due to river cleaning operations (Gippel et al., 1996;
Crook \& Robertson, 1999; Maddock, 1999). Wetland drainage and other landscape changes, combined with over-fishing, effectively eliminated $L$. canadensis from much of its range (Toweill \& Tabor, 1982; Melquist \& Dronkert, 1987). Similar causes have been suggested for the decline of L. lutra and Mustela lutreola in Europe (Foster-Turley et al., 1990; Macdonald et al., 2002b). Consequently, it is clear that river canalization or riparian vegetation removal is likely to affect the use of rivers and streams by the southern river otter, as these river management approaches destroy the habitat of their prey (Boon, 1992; Crook \& Robertson, 1999).

The conservation of the southern river otter is inextricably linked to the conservation of the habitat of the otter's prey and the availability of suitable sites for shelters. The findings of this study emphasise this relationship and indicate that activities which detrimentally affect the otter's habitat and that of its prey, such as dredging and canalization of rivers and streams, and projects that engage in the removal of riparian vegetation, woody debris and swamp forest associated with rivers and streams, should be avoided in southern Chile. Consideration should be given instead to river and stream management options that are sympathetic to the conservation of the southern river otter and its habitat.

\section{Acknowledgements}

We are very grateful to the Frankfurt Zoological Society for funding this research (Project FZS 1247/98 - CODEFF, Chile). We would like to thank the Comite Nacional Pro Defensa de la Fauna y Flora (CODEFF), the Earthwatch Institute and the Instituto de Ecología y Evolución of the Universidad Austral de Chile for financial support and the provision of equipment, and Dr Fernando H. Jara for his assistance with the statistical analysis. We would also like to extend our thanks to the Earthwatch Institute volunteers for their help during the surveys, to Drs John F. Organ and Milton Gallardo for reviewing the manuscript and to Georgina Sutherland for proofreading the manuscript.

\section{References}

Andrews, E. (1989) Assessment of the value of river for otters (Lutra lutra). Regulated Rivers Research and Management, 4, 199-202.

Benke, A.C., van Arsdall, T.C., Jr, \& Gillespie, D.M. (1984) Invertebrate productivity in a subtropical blackwater river: the importance of habitat and life history. Ecological Monographs, 54, 25-63. 
Boon, P.J. (1992) Essential elements in the case for river conservation. In River Conservation and Management (eds P.J. Boon, P. Calow \& G.E. Petts), pp. 11-33. John Wiley, New York, USA.

Campos, H. (1985) Distribution of the fishes in the Andean rivers in the south of Chile. Archiv für Hydrobiologie, 104, 169-191.

Chehébar, C., Gallur, A., Giannico, G., Gottelli, M. \& Yorio, P. (1986) A survey of the Southern river otter Lutra provocax in Lanin, Puelo and Los Alerces National Parks, Argentina and an evaluation of its conservation status. Biological Conservation, 38, 293-304.

Crook, D.A. \& Robertson, A.I. (1999) Relationships between riverine fish and woody debris: implications for lowland rivers. Marine and Freshwater Research, 50, 941-953.

Dubuc, L.J., Krohn, W.B. \& Owen, R.B. (1990) Predicting occurrence of river otters by habitat on Mount Desert Island, Maine. Journal of Wildlife Management, 54, 594-599.

Foster-Turley, P., Macdonald, S. \& Mason, C (eds) (1990) Otters. An Action Plan for their Conservation. IUCN, Gland, Switzerland.

Fox, A. (1999) The role of habitat enhancement in the return of the European otter (Lutra lutra) to Northumberland. Journal of the Chartered Institution of Water and Environmental Management, 13, 79-83.

Gippel, C.J., Finlayson, B.L. \& O’Neill, I.C. (1996) Distribution and hydraulic significance of large woody debris in a lowland Australian river. Hydrobiologia, 318, 179-194.

Guajardo, M.A.R. (2001) Concursos de drenaje, resultados de la ley $\mathrm{N}^{\circ}$ 18.450. Secretario Ejecutivo, Comisión Nacional de Riego. In Proceedings Seminario realidad y perspectivas de la habilitación de suelos mal drenados en el sur de Chile, IX y X regiones. Comisión Nacional de Riego, Sociedad Chilena de la Ciencia del Suelo, Universidad Austral de Chile, Valdivia, Chile.

IUCN (2002) 2002 IUCN Red List of Threatened Species. IUCN, Gland, Switzerland [http:/ / www.redlist.org, accessed 17 July 2003].

Hutchings, M.R. \& White, P.C.L. (2000) Mustelid scent-marking in managed ecosystems: implications for population management. Mammal Review, 30, 157-169.

Jenkins, D. \& Burrows, G.O. (1980) Ecology of otters in northern Scotland. III. The use of spraints as indicator of otter (Lutra lutra) density and distribution. Journal of Animal Ecology, 49, 755-774.

Kirby, K.N. (1993) Advanced Data Analysis with SYSTAT. Van Nostrand Reinhold, New York, USA.

Krebs, C.J. (1989) Ecological Methodology. Harper Collins, New York, USA.

Kruuk, H. (1992) Scent marking by otters (Lutra lutra): signaling the use of resources. Behavioural Ecology, 3, 133-140.

Kruuk, H., Carss, D.N., Conroy, J.W.H. \& Durbin, L. (1993) Otter (Lutra lutra L.) numbers and fish productivity in rivers in north-east Scotland. Symposium of the Zoological Society of London, 65, 171-191.

Kruuk, H. (1995) Wild Otters. Predation and populations. Oxford University Press, Oxford, UK.

Macdonald, S.M., Mason, C.F. \& Coghill, I.S. (1978) The otter and its conservation in the River Teme catchment. Journal of Applied Ecology, 15, 373-384.

Macdonald, S.M. \& Mason, C.F. (1987) Seasonal marking in an otter population. Acta Theriologica, 32, 449-462.
Macdonald, D.W., Sidorovich, V.E., Anisomova, E.I., Sidorovich, N.V. \& Johnson, P.J. (2002a) The impact of American mink Mustela vison and European mink Mustela lutreola on water voles Arvicola terrestris in Belarus. Ecography, 25, 295-302.

Macdonald, D.W., Sidorovich, V.E., Maran, T. \& Kruuk, H. (2002b) The Darwin Initiative. European Mink, Mustela lutreola: Analyses for Conservation. Wildlife Conservation Research Unit, University of Oxford, UK.

Maddock, I. (1999) The importance of physical habitat assessment for evaluating river health. Freshwater Biology, 41, 373-391.

Madsen, A.B. \& Prang, A. (2001) Habitat factors and the presence or absence of otters Lutra lutra in Denmark. Acta Theriologica, 46, 171-179.

Medina, G. (1996) Conservation and status of Lutra provocax in Chile. Pacific Conservation Biology, 2, 414-419.

Medina, G. (1998) Seasonal variation and changes in the diet of southern river otter in different freshwater habitats in Chile. Acta Theriologica, 43, 285-292.

Melquist, W.E. (1984) Status survey of otters (Lutrinae) and spotted cats (Felidae) in Latin America. IUCN, Gland, Switzerland.

Melquist, W.E. \& Hornocker, M.G. (1983) Ecology of river otter in west central Idaho. Wildife Monographs, 83, 1-60.

Melquist, W.E. \& Dronkert, E. (1987) River otter. In Wild Furbearer Management and Conservation in North America (eds M. Novak, J.A. Baker, M.E. Obbard \& B. Malloch), pp. 627-641. Ministry of Natural Resources, Ontario, Canada.

Montgomery, D.R. \& Buffington, J.M. (1998) Channel processes, classification, and response. In River Ecology and Management Lessons from the Pacific Coastal Ecoregion (eds R.J. Naiman \& R.E. Bilby), pp. 13-42. Springer, New York, USA.

Newman, D.G. \& Griffin, C.R. (1994) Wetland use by river otters in Massachusetts. Journal of Wildlife Management, 58, 18-23.

Osgood, W.H. (1943) The Mammals of Chile. Publication of the Field Museum of Natural History, Zoological Series, 30, 1-268.

Perrin, M.R. \& Carugati, C. (2000) Habitat use by the Cape clawless otter and the spotted-necked otter in the KwaZuluNatal Drakensberg, South Africa. South African Journal of Wildlife Research, 30, 103-113.

Ramirez, C., Ferriere, F. \& Figueroa, H. (1983) Estudio Fitosociológico de los bosques pantanosos templados del sur de Chile. Revista Chilena de Historia Natural, 56, 11-26.

Ruiz-Olmo, J. \& Gosálbez, J. (1997) Observations on the sprainting behaviour of the Otter Lutra lutra in NE Spain. Acta Theriologica, 42, 259-270.

Smock, L.A., Gilinsky, E. \& Stoneburner, D.L. (1985) Mocroinvertebrate production in a south-eastern United State blackwater stream. Ecology, 66, 1491-1503.

Thome, T.J., Thomas, C.J., Dunstone, N. \& Evans, P.R. (1998) The relationship between riverbank habitat and prey availability and the distribution of otter (Lutra lutra) signs: an analysis using a geographical information system. In Behavioural and Ecology of Riparian Mammals (eds N. Dunstone \& M. Gorman), pp. 135-157. Cambridge University Press, Cambridge, UK.

Thomas, D.L \& Taylor, E.J. (1990) Study designs and test for comparing resource use and availability. Journal of Wildlife Management, 54, 322-330. 
Toweill, D.E. \& Tabor, J.E. (1982) The northern river otter (Lutra canadensis). In Wild Mammals of North America: Biology, Management and Ecology (eds J.A. Chapman \& G.A. Feldhamer), pp. 688 - Johns Hopkins University Press, Baltimore, USA.

White, P.C.L., McClean, C.J. \& Woodrofe, G.L. (in press) Factors affecting the success of an otter (Lutra lutra) reinforcement programme, as identified by posttranslocation monitoring. Biological Conservation. Wilkinson, L., Blank, G. \& Gruber, C. (1996) Desktop data analysis with SYSTAT. Prentice Hall, New Jersey, USA.

\section{Biographical sketches}

Gonzalo Medina-Vogel is currently studying the decline of southern river otter Lontra provocax and marine otter L. felina in the wild. His other research interest include aspects of ecology relevant to solving problems in carnivore conservation.

Vera S. Kaufman has carried out research on the marking patterns of southern river otters.

René Monsalve has been working with southern river otter projects since 1992 and also with projects concerning the conservation of other threatened carnivores in Chile.

Vicente Gomez has been involved with otter research since 1998 and is currently working on the radio-tracking of southern river otters in southern Chile. 